\title{
Population genetic structure of the endangered freshwater crayfish Austropotamobius pallipes, assessed using RAPD markers
}

\author{
NICOLAS GOUIN*†, FREDERIC GRANDJEAN $\uparrow$, DIDIER BOUCHON $\uparrow$, \\ JULIAN D. REYNOLDS $\$$ \& CATHERINE SOUTY-GROSSET $\dagger$ \\ $\dagger$ Laboratoire de Génétique et Biologie des Populations de Crustacés, UMR CNRS 6556, Université de Poitiers, \\ 40 Avenue du recteur Pineau, F-86022 Poitiers cedex, France and $\$$ Department of Zoology, \\ University of Dublin-Trinity College, Dublin 2, Ireland
}

\begin{abstract}
Random amplified polymorphic DNA (RAPD) analysis was performed to characterize the genetic diversity of Austropotamobius pallipes, a threatened freshwater crayfish native to Europe. Four decamer primers which generated six unambiguous polymorphic bands were used to analyse crayfish from 21 populations sampled in the major part of its range. Genetic diversity within populations of A. pallipes, estimated by Shannon's diversity index, ranged from 0 to 0.446 with a mean of 0.159 . A UPGMA dendrogram constructed from pairwise $\Phi_{\mathrm{ST}}$ values between populations, revealed three clusters corresponding to populations sampled in the southern, northwestern and eastern part of its range. AMOVA analysis revealed a high genetic structure of $A$. pallipes populations $\Phi_{\mathrm{ST}}=0.814$, with $73.11 \%$ of the genetic variation distributed between these clusters. It suggests a historical geographical separation of these groups into three refugial areas, probably in the Rhine, Mediterranean and Atlantic basins during recent glaciations. The close genetic relationships between English and western French populations are in accordance with a natural postglacial origin of English populations from individuals having survived in an Atlantic refugium. However, the present results suggest that the Irish stock originated from a human translocation of individuals from an Atlantic refugium.
\end{abstract}

Keywords: Austropotamobius pallipes, biogeography, Crustacea, genetic structure, RAPD.

\section{Introduction}

Climatic change during the middle to late Pleistocene had a profound impact on the distribution and the genetic structure of animal and plant communities in the Northern Hemisphere (Hewitt, 1996). During glaciations, species were confined to separate southern refugia where they avoided extinction. The retreat of the ice allowed postglacial dispersal opportunities from these refugia. In most species, populations from glaciated vs. nonglaciated regions show differences in their genetic diversity and phylogeographical structure. Northern populations characteristically have reduced levels of genetic variation when compared with southern conspecific populations (Hewitt, 1996). This results from the colonization process, which implies that successive bottlenecks have lead to the loss of genetic

*Correspondence. E-mail: gene.crust@univ-poitiers.fr diversity in newly founded populations. Such a process tends to favour the accumulation of genetic variations between populations originates from different refugia. Thus, intraspecific phylogeographical structure will correspond to refugia where species have persisted.

The crayfish Austropotamobius pallipes (Lereboullet) is endemic to Western Europe. Until recently, considerable taxonomic confusion persisted in the literature about this species complex as a consequence of the poor discrimination of morphological criteria. Based on sequences from mitochondrial 16S rRNA gene, Grandjean et al. (2000a) proposed a revised classification based on four species: A. torrentium (mainly distributed in Switzerland, Austria and Balkans), A. berndhauseri (Switzerland), A. italicus (Balkans, Italy, Spain) and A. pallipes (France, England and Ireland). These authors explained the present distribution in terms of postglacial recolonization events or human translocations from three main glacial refugia located in Balkans, 
Italy and France (Grandjean et al., 2000a, 2001). Although still widely encountered, many native populations have decreased in abundance or become extinct, as a result of human activity, competition with exotic crayfishes and numerous epizootics. This crayfish is now confined to small brooks located in the headwaters of hydrographic basins and is classed as an endangered and rare species (Baillie \& Groombridge, 1996).

Previous studies of the genetic structure of the whiteclawed crayfish have mainly focused on allozyme variation in Austropotamobius italicus. Santucci et al. (1997) and Lörtscher et al. (1997) reported a lack of genetic intrapopulational variability with a strong genetic structure of populations that could be explained both by multiple refugial area and by drastic recent reduction in size of populations. In Austropotamobius pallipes, results from allozyme analysis are very sparse. Attard \& Vianet (1985) revealed an absence of variability among five populations, and from a restricted sample, Santucci et al. (1997) and Largiadèr et al. (2000) recently confirmed the lack of variability within this species. The analysis of mitochondrial DNA by restriction fragment length polymorphism revealed a low genetic divergence within and between $A$. pallipes populations sampled in western France (Grandjean et al., 1997; Souty-Grosset et al., 1997). As none of the mtDNA regions useful in population genetics, such as the control region, are stored in GeneBank, the use of neutral nuclear markers more variable than allozymes appears to be essential to the study of genetic variation within $A$. pallipes. Until microsatellite loci are available in this species, an alternative method is to use random amplified polymorphic DNA (RAPD). It provides an arbitrary sample of the genome and can generate unlimited numbers of markers which are inherited mainly as dominant characters (Williams et al., 1990). This technique - simple and quick to perform because no previous knowledge of DNA sequences is required can be a powerful tool for initial assessment of genetic diversity (Fritsch \& Rieseberg, 1996).

The objective of the present study is to evaluate the usefulness of RAPD to assess the level of genetic diversity within populations of $A$. pallipes and to understand the partitioning of this variation throughout a large part of its range.

\section{Materials and methods}

\section{Sample collection}

Specimens were collected from 21 locations in Western Europe: 16 populations in France, one in Germany, two in England and two in Ireland (Fig. 1, Table 1). In France, sampling was carried out within three major

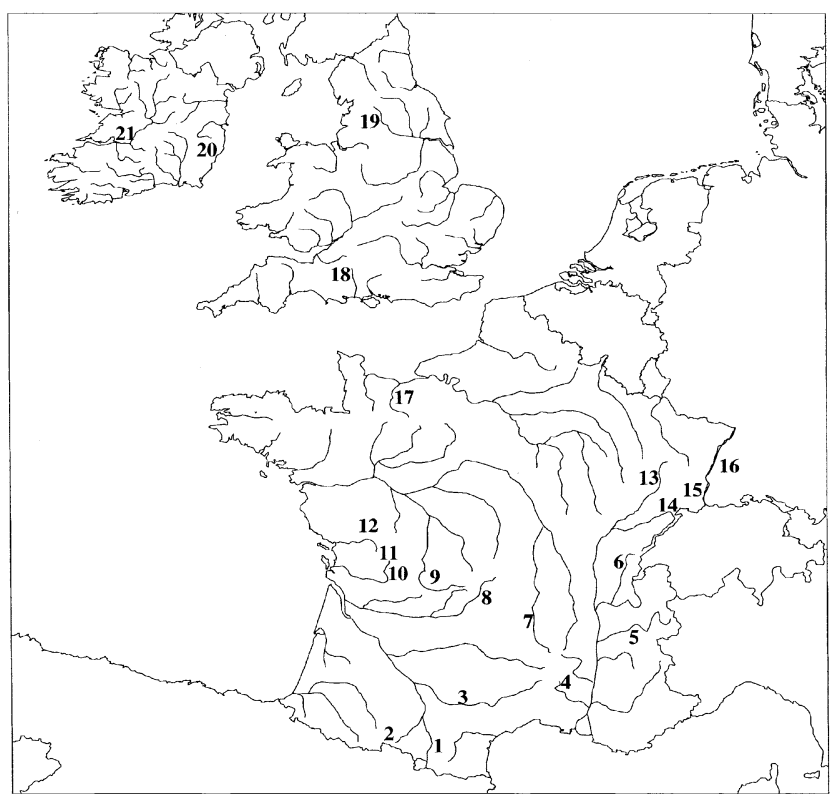

Fig. 1 Geographical location of Austropotamobius pallipes populations sampled in Western Europe (numbers as in Table 1).

catchments (Loire, Garonne and Rhône) where populations are still widely encountered. One claw or a pereiopod of the fourth pair was taken from each individual and stored in pure ethanol. The total number of individuals per sample is listed in Table 1.

\section{DNA isolation}

Total DNA was isolated from muscle. Tissues were rehydrated for $2 \mathrm{~min}$ in sterile water and ground with plastic pestles in microcentrifuge tubes containing $100 \mathrm{~mm}$ Tris, $10 \mathrm{~mm}$ EDTA, $100 \mathrm{~mm} \mathrm{NaCl}, 0.1 \%$ SDS, $50 \mathrm{~mm}$ DTT and $10 \mu \mathrm{L} \mathrm{mL} \mathrm{m}^{-1}$ proteinase $\mathrm{K}(\mathrm{pH}=8)$. Samples were incubated at $37^{\circ} \mathrm{C}$ for $4 \mathrm{~h}$ and DNA extracted twice with phenol/chloroform/isoamyl alcohol (25:24:1) followed by one additional chloroform wash. The DNA was then precipitated with one volume of isopropanol and $1 / 10$ volume of $3 \mathrm{~m}(\mathrm{pH}=5.2)$ sodium acetate. Finally the DNA was dried and resuspended in sterile water.

\section{RAPD amplification}

PCR reactions were performed in a total volume of $25 \mu \mathrm{L}$ containing: $1 \times$ Taq polymerase buffer (Promega), $2 \mathrm{mM} \mathrm{MgCl}_{2}, 100 \mu \mathrm{M}$ each dNTP, 5 pmol primer, $0.75 \mathrm{U}$ Taq polymerase (Promega) and $15 \mathrm{ng}$ template DNA. This strict protocol must be followed to achieve reproducibility and visibility of the amplification products. The optimal cycling programme was $2 \mathrm{~min}$ at $94^{\circ} \mathrm{C}$, 


\begin{tabular}{|c|c|c|c|}
\hline Population & Region & Major drainage & $N$ \\
\hline 1 Artix & SW France & Garonne & 16 \\
\hline 2 Arbon & SW France & Garonne & 12 \\
\hline 3 Fourtounas & SW France & Garonne & 12 \\
\hline 4 Gardon de St Martin & SE France & Rhône & 9 \\
\hline 5 Isère & SE France & Rhône & 15 \\
\hline 6 Selignac & SE France & Rhône & 15 \\
\hline 7 Besque & Central France & Loire & 15 \\
\hline 8 Mortagne & Central France & Garonne & 9 \\
\hline 9 Crochatière & Western France & Loire & 20 \\
\hline 10 Fontaine St Pierre & Western France & Charente & 11 \\
\hline 11 Magnerolles & Western France & Sèvre Niortaise & 10 \\
\hline 12 Puits d'Enfer & Western France & Sèvre Niortaise & 8 \\
\hline 13 Rupt & Eastern France & Rhône & 23 \\
\hline 14 Madeleine & Eastern France & Rhône & 10 \\
\hline 15 Lucelle & Eastern France & Rhine & 10 \\
\hline 16 Fribourg & Germany & Rhine & 9 \\
\hline 17 Val renard & Northern France & Orne & 11 \\
\hline 18 Broadmead brook & Great Britain & Avon & 6 \\
\hline 19 River Wharfe & Great Britain & Wharfe & 6 \\
\hline 20 Blessington lake & Ireland & Liffey & 10 \\
\hline 21 Cloughjordan & Ireland & Shannon & 15 \\
\hline
\end{tabular}

Table 1 Populations of Austropotamobius pallipes sampled for RAPD analysis: number (bold characters), name, geographical locations, major drainages and number of individuals sampled $(N)$
Table 2 RAPD primers used in the study, their sequence, the name and the approximate size in base pairs of scored polymorphic markers

\begin{tabular}{lccr}
\hline & $\begin{array}{c}\text { Sequence } \\
\left(5^{\prime} \rightarrow 3^{\prime}\right)\end{array}$ & $\begin{array}{c}\text { Scored } \\
\text { polymorphic } \\
\text { loci }\end{array}$ & $\begin{array}{r}\text { Size } \\
(\mathrm{bp})\end{array}$ \\
\hline OPC-04 & CCGCATCTAC & C04-1 & 1344 \\
& & C04-2 & 627 \\
OPC-19 & GTTGCCAGCC & C19-1 & 520 \\
OPA-01 & CAGGCCCTTC & A01-1 & 1708 \\
& & A01-2 & 1600 \\
OPA-10 & GTGATCGCAG & A10-1 & 795 \\
\hline
\end{tabular}

$1 \mathrm{~min} / 35^{\circ} \mathrm{C}, 2 \mathrm{~min} / 72^{\circ} \mathrm{C}$ followed by $1 \mathrm{~min} / 94^{\circ} \mathrm{C}, 1 \mathrm{~min} /$ $35^{\circ} \mathrm{C}, 2 \mathrm{~min} / 72^{\circ} \mathrm{C}$ for 44 cycles and a final extension of $5 \mathrm{~min} / 72^{\circ} \mathrm{C}$, using a Trio-Thermoblock (BIOMETRA $\mathrm{GmBH}$, Göttingen, Germany). A search for polymorphism was performed from two sets (kits A and C) of 20 10-mer primers (Operon Technologies, Inc., USA). Four primers that revealed polymorphism were selected to give positive and reproducible results: OPC-04, OPC-19, OPA-01, and OPA-10 (Table 2). A negative control (without DNA template) was added to every amplification run to ensure that scorable fragments were not artefacts. Amplified products were separated in $1.5 \%$ agarose gels in $1 \times$ TAE ( $40 \mathrm{~mm}$ Tris base, $20 \mathrm{~mm}$ Acetic acid, 2 mm EDTA, $\mathrm{pH}=8.4$ ), stained with ethidium bromide and visualized on a UV transilluminator $(254 \mathrm{~nm})$.

\section{Scoring of RAPD markers}

Bands were scored by placing the negatives of each photograph over a lightbox. By comparing fingerprints within and between gels, it was possible to identify RAPD fragments that were always present with a particular primer and those which were polymorphic. Only bands of high intensity were taken into account because they are the most reproducible (Skroch \& Nienhuis, 1995). RAPD markers were then scored if they displayed a clear polymorphism (i.e presence or absence) with no faint amplification. If there was a doubt about the reliability of a band, the reaction was repeated before scoring definitively or not.

\section{Data analysis}

Calculation of allele frequencies by compensating for deviation from Hardy-Weinberg equilibrium (Lynch \& Milligan, 1994) was not attempted. In the absence of more-detailed characterization of RAPD markers, their use as genetic phenotypes would appear prudent. The phenotype of a distinct locus was therefore considered as the presence (1) or absence (0) of each polymorphic band. Shannon's diversity index was calculated to provide a relative estimate of the degree of genetic variation within each population using POPGENE 1.31 (Yeh, 1999):

$H_{0}=\sum P_{i} \log _{2} \mathrm{P}_{\mathrm{I}}$,

(c) The Genetics Society of Great Britain, Heredity, 87, 80-87. 
where $P_{i}$ is the frequency of each RAPD band. The correlation between intrapopulational diversity and the latitudinal origin of the populations was assessed using JMP software (version 3.2.2, SAS Institute Inc.). Genetic distances between pairs of populations were expressed as $\Phi_{\mathrm{ST}}$ values, which are similar to estimates of $F_{\text {ST }}$ (Excoffier et al., 1992). ARLEQUIN 1.1 software (Schneider et al., 1997) was used to compute pairwise $\Phi_{\mathrm{ST}}$ between populations and to test for genetic differentiation between all populations. This test, analogous to Fisher's exact test, is based on the hypothesis of random distribution of individuals between pairs of populations (Raymond \& Rousset, 1995). Population clustering was performed from $\Phi_{\mathrm{ST}}$ estimates using the UPGMA method included in the software package PHYLIP 3.5c (Felsenstein, 1993). We applied the analysis of molecular variance (AMOvA; Excoffier et al., 1992) to assess the partitioning of genetic variation between populations sampled in this study, according to the UPGMA clustering. Populations sampled in southern and central France were grouped into cluster I; those located in western and northern France, Ireland and England comprised cluster II; and populations from eastern France and Germany comprised cluster III. $\chi^{2}$ statistics (Roff \& Bentzen, 1989) were then used to test the degree of heterogeneity in frequency distributions of the RAPD phenotypes between populations. The significance level was tested by 1000 Monte Carlo randomizations using
MONTE program from the REAP 4.0 package (McElroy et al., 1992).

\section{Results}

The four random primers used in the survey generated a total of six unambiguous polymorphic loci, ranging in size from 520 to $1700 \mathrm{bp}$ (Table 2). As presented in Table 3, all loci globally showed similar intrapopulation levels of variation (from 0.092 to 0.220 ). Most of them were fixed in some populations, which could explain the genetic differentiation observed between populations. The mean genetic diversity within populations estimated by Shannon's indices ranged from 0.000 to 0.446 and is not related to the latitudinal origin of the populations $\left(r^{2}=0.096 ; P=0.17\right)$. Three populations revealed no polymorphism - Artix (1), Arbon (2) and Mortagne (8) - whereas the most variable was Magnerolles (11). The mean value of the Shannon's estimates was 0.159. The UPGMA dendrogram obtained from pairwise $\Phi_{\mathrm{ST}}$ (Table 4) revealed three main clusters (Fig. 2) supported by high $P$-values of genetic differentiation between populations (Table 4).

According to the AMOva (Table 5), the major part of the total genetic variance was expressed between the three clusters $(73.11 \%)$, whereas $18.58 \%$ was estimated within populations. Only $8.31 \%$ of the total variation was expressed among populations within clusters

Table 3 Genetic diversity estimates within populations of Austropotamobius pallipes using Shannon's diversity index

\begin{tabular}{llllllll}
\hline Population & $\mathrm{C} 04-1$ & $\mathrm{C} 04-2$ & $\mathrm{C} 19-1$ & $\mathrm{~A} 01-1$ & $\mathrm{~A} 01-2$ & $\mathrm{~A} 10-1$ & $H_{0}$ \\
\hline 1 Artix & 0.000 & 0.000 & 0.000 & 0.000 & 0.000 & 0.000 & 0.000 \\
2 Arbon & 0.000 & 0.000 & 0.000 & 0.000 & 0.000 & 0.000 & 0.000 \\
3 Fourtounas & 0.000 & 0.000 & 0.000 & 0.000 & 0.000 & 0.176 & 0.029 \\
4 Gardon de St Martin & 0.219 & 0.000 & 0.000 & 0.000 & 0.000 & 0.219 & 0.073 \\
5 Isère & 0.000 & 0.000 & 0.000 & 0.000 & 0.000 & 0.477 & 0.079 \\
6 Selignac & 0.000 & 0.684 & 0.000 & 0.000 & 0.000 & 0.000 & 0.114 \\
7 Besque & 0.000 & 0.000 & 0.000 & 0.000 & 0.000 & 0.411 & 0.068 \\
8 Mortagne & 0.000 & 0.000 & 0.000 & 0.000 & 0.000 & 0.000 & 0.000 \\
9 Crochatière & 0.000 & 0.202 & 0.000 & 0.667 & 0.534 & 0.687 & 0.348 \\
10 Fontaine St Pierre & 0.000 & 0.631 & 0.000 & 0.612 & 0.575 & 0.188 & 0.334 \\
11 Magnerolles & 0.000 & 0.636 & 0.000 & 0.691 & 0.671 & 0.681 & 0.446 \\
12 Puits d'Enfer & 0.000 & 0.000 & 0.000 & 0.605 & 0.668 & 0.000 & 0.212 \\
13 Rupt & 0.618 & 0.000 & 0.691 & 0.000 & 0.000 & 0.000 & 0.218 \\
14 Madeleine & 0.000 & 0.000 & 0.624 & 0.000 & 0.000 & 0.000 & 0.104 \\
15 Lucelle & 0.534 & 0.000 & 0.624 & 0.000 & 0.000 & 0.000 & 0.193 \\
16 Fribourg & 0.691 & 0.636 & 0.000 & 0.000 & 0.000 & 0.000 & 0.221 \\
17 Val renard & 0.000 & 0.672 & 0.000 & 0.000 & 0.000 & 0.000 & 0.112 \\
18 Broadmead brook & 0.000 & 0.534 & 0.000 & 0.000 & 0.534 & 0.687 & 0.292 \\
19 River Wharfe & 0.000 & 0.000 & 0.000 & 0.000 & 0.605 & 0.000 & 0.101 \\
20 Blessington lake & 0.000 & 0.636 & 0.000 & 0.000 & 0.363 & 0.636 & 0.272 \\
21 Cloughjordan & 0.000 & 0.000 & 0.000 & 0.000 & 0.148 & 0.571 & 0.119 \\
Mean values & 0.098 & 0.220 & 0.092 & 0.123 & 0.195 & 0.225 & 0.159 \\
\hline
\end{tabular}

(C) The Genetics Society of Great Britain, Heredity, 87, 80-87. 
Table 4 Pairwise $\Phi_{\mathrm{ST}}$ values illustrating differences between populations of Austropotamobius pallipes (numbers as in Table 1). $\Phi_{\mathrm{ST}}$ values are given below the diagonal, and the associated probabilities of genetic differentiation are given above

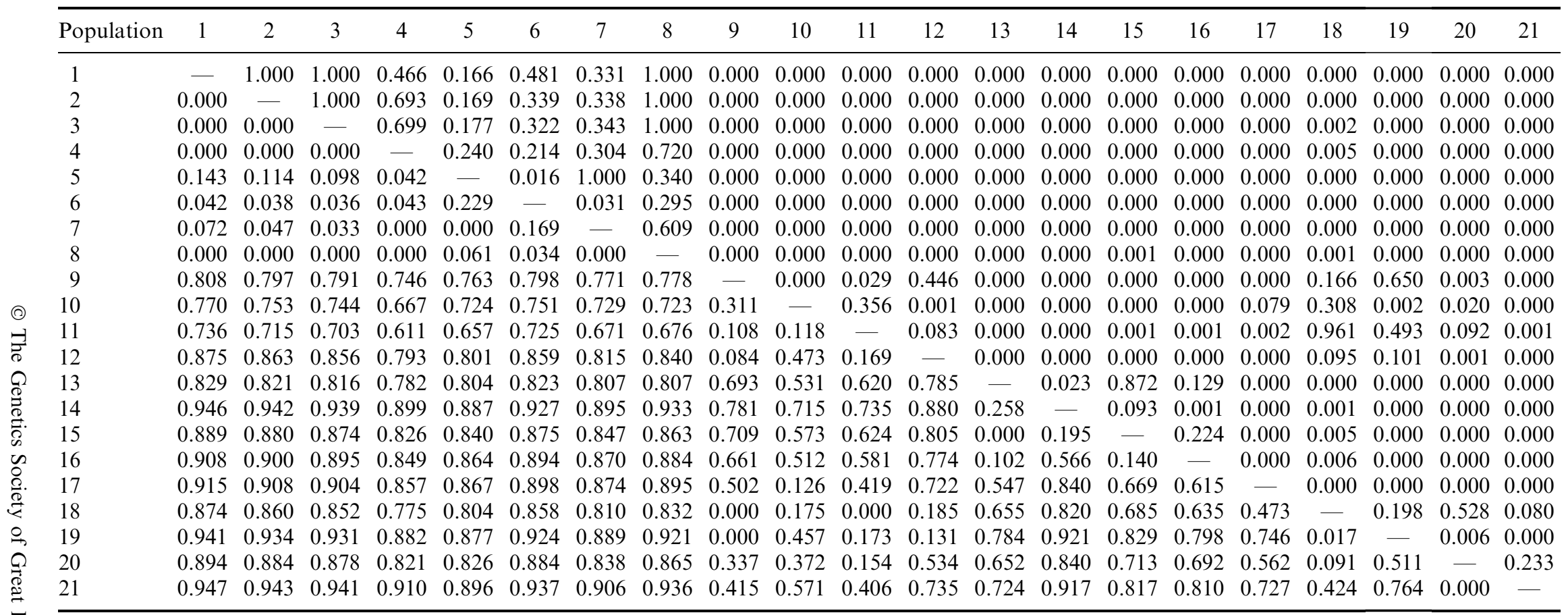




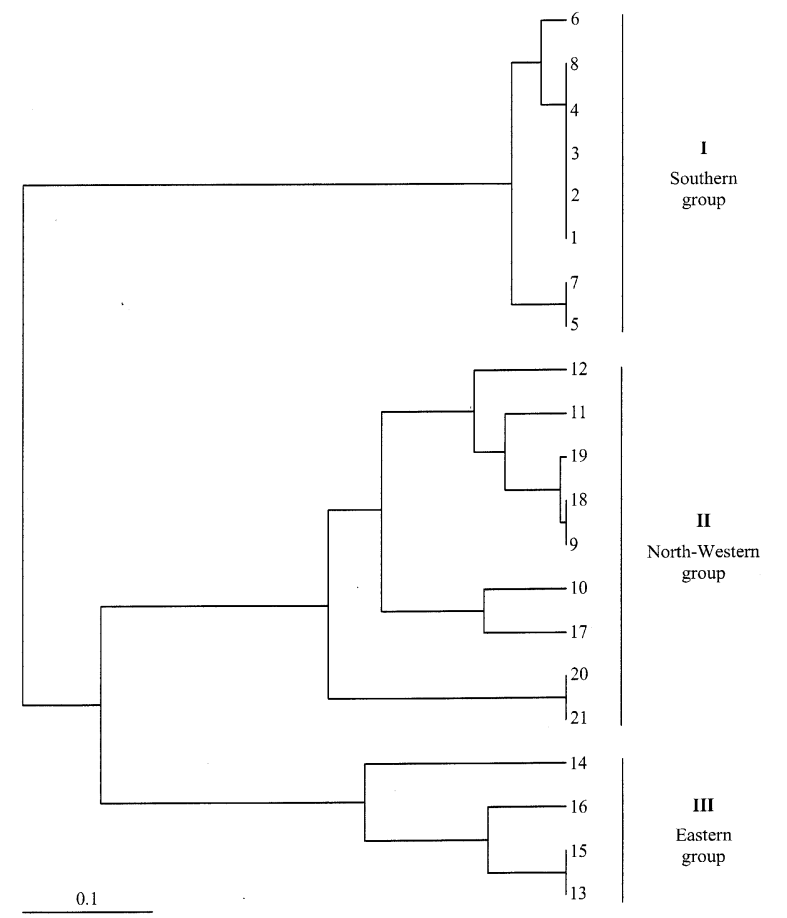

Fig. 2 Unrooted UPGMA dendrogram based on pairwise $\Phi_{\mathrm{ST}}$ values among Austropotamobius pallipes populations (numbers as in Table 1).

(Table 5). These results revealed a high genetic structure between the clusters, caused mainly by differences in fixed loci between them. Within cluster II, differences in haplotype frequencies were not significant $\left(\chi^{2}=\right.$ 13.21, $P=0.211$ ) between British and northern French populations, whereas statistically significant differences among Irish and both British-French populations were observed $\left(\chi^{2}=54.18, P<0.0001\right)$. Within cluster III, no significant difference was revealed between the two populations $(15 ; 16$ in Fig. 1) sampled in the Rhine basin and the two populations $(13 ; 14)$ sampled in the Rhône sub-basin of the Saône $\left(\chi^{2}=7.62, P=0.092\right)$.

\section{Discussion}

\section{Variability within populations}

Crustaceans are known to display relatively low levels of allozyme polymorphism $(H=0.082$ for Crustaceans; Nevo et al., 1984). In A. pallipes, Attard \& Vianet
(1985) reported a mean heterozygosity lower than 0.028 and Santucci et al. (1997) report a value of 0.001. In this study, RAPD markers have revealed a higher level of diversity $\left(H_{0}=0.159\right)$ based on Shannon's diversity estimates. Nevertheless the intrapopulation diversity did not follow a latitudinal gradient (Hewitt, 1996) in relation to geological events in Europe during the Pleistocene. In most European species, the populations located in the south of the species' range show a stronger intrapopulation diversity than those located in northern areas. This has been explained by postglacial recolonization of northern regions from populations that have survived in southern refugial areas during the last ice ages. However, the lowest levels of genetic diversity were observed in $A$. pallipes populations sampled in southern and central France and the highest in populations located in western France. Nevertheless differences in local population sizes are known to influence the degree of genetic variation within and between populations (Wright, 1978; Lande, 1995). In a recent study of the dynamics and life history of white-clawed crayfish, Grandjean et al. (2000b) reported a large population size within the brook of Crochatière, which has also been observed in the brook of Magnerolles (unpubl. data). These two populations also displayed the highest genetic diversity. Thus, even if similar data are lacking from other populations, genetic diversity within sites might be influenced by population size in A. pallipes. Similar observations have been reported for other freshwater species, in particular among fish (Ward et al., 1994; Hänfling \& Brandl, 1997).

\section{Variability among populations}

RAPD analysis showed that French populations were not panmictic. A considerable proportion of the total genetic variance was attributable to differences among geographical regions. UPGMA analysis based on $\Phi_{\mathrm{ST}}$ clearly revealed a geographical structuring of populations, with three main clusters (I, II and III) in A. pallipes corresponding, respectively, to the southern, northwestern and eastern parts of its range. This result supports the hypothesis that each of these clusters include genetically differentiated populations. By contrast, previous allozyme data analysis revealed no genetic structuring of $A$. pallipes populations (Santucci et al., 1997; Lörtscher et al., 1997). The geographical
Table 5 Analysis of molecular variance (AMOVA) for the 21 populations of Austropotamobius pallipes. Significance levels are based on 1000 permutations. $\uparrow 1$ degree of freedom

\begin{tabular}{lrrrr}
\hline Source of variation & d.f. $\dagger$ & Variation & $\Phi$ statistics & $P$-value \\
\hline Among groups & 2 & 73.11 & $\Phi_{\mathrm{CT}}=0.731$ & $<0.0001$ \\
Among populations within groups & 18 & 8.31 & $\Phi_{\mathrm{SC}}=0.309$ & $<0.0001$ \\
Within populations & 230 & 18.58 & $\Phi_{\mathrm{ST}}=0.814$ & $<0.0001$ \\
\hline
\end{tabular}


pattern of the genetic distribution, supported by the present data, is similar to those obtained in other European freshwater organisms such as brown trout (Guyomard, 1989) and barbel (Persat \& Berrebi, 1990). According to Guyomard (1989), these icthyofaunal provinces seem to be related to historical events in the most recent glacial periods, wherein aquatic species would have found refuge in the three main drainage basins (i.e. Danube, Mediterranean and Atlantic); recolonization of northwestern Europe would have occurred from these refugia. However, A. pallipes does not occur in the Danube drainage, apart from one population recently introduced from northern Italy (Fuereder \& Machino, 1995). As only A. italicus is represented, it appears doubtful that eastern populations of A. pallipes have a postpleistocene origin from the Danube refugium. From the present results, we suggest that the Rhine drainage could have been a refugium for $A$. pallipes. This assumption is in accordance with the work performed by Persat \& Berrebi (1990), which explained the present distribution of the barbel Barbus barbus by the existence of two glacial refugia (Mosel and Meuse sub-basins) in the Rhine basin during the last ice age. This result refuted the proposal by Largiadèr et al. (2000) of a human origin for crayfish populations within the Rhine basin from individuals sampled in the Rhône basin. Thus, the phylogeographical boundaries of $A$. pallipes lineages indicate that this species persisted in all of the major refugia available to western European freshwater fish: the Mediterranean coast (cluster I), the Atlantic coast (cluster II) and the Rhine (cluster III), apart from the Danube refugium, which probably harboured A. italicus.

In the present study, RAPD markers revealed a strong genetic homogeneity between populations of A. pallipes from the Rhine and from the Saône subbasin, that suggests interdrainage gene flow between the Rhine and Rhône basins. According to this result, a natural colonization of $A$. pallipes from the Rhine to the Rhône basin in eastern France may be assumed. Villinger (1986) maintained that the separation of the Rhône and Rhine basins occurred in the middle Pliocene. However, he also reported the possibility of later temporary connections between the basins during the Quaternary as a result of ice caps and captures of tributaries. So, a recent colonization was thus possible by headwater connections of the palaeo-Rhine-Rhone. This connection has been proposed in other freshwater organisms to explain the presence of genotypes originating from the Danube in the Rhône drainage (Persat \& Berrebi, 1990). Thus, in A pallipes, the Rhône hydrographic system has been recolonized by animals from both Mediterranean and Rhine refugia. This result suggests the existence of postglacial secondary contact between animals originating from these two refugia, which must be verified by further investigation.

Concerning cluster II, populations located in western France, England and Ireland could be derived from animals that survived in the Atlantic refugium. No genetic differentiation was observed between French and British populations. This result is in accordance with those obtained from mitochondrial DNA analysis (Grandjean et al., 1997), which supports the assumption of recent gene flow between them. Thus, recent colonization of Great Britain by crayfish of Atlantic origin is evident, possibly via a postglacial stream connection between the two countries (Albrecht, 1983), insufficient time having passed to result in genetic differentiation. In contrast, the significant genetic differentiation between Irish populations and the clade II populations $\left(\chi^{2}=54.18, P<0.0001\right)$ could indicate the fragmentation of the Atlantic refugium into two isolates. However, A. pallipes could not have survived the last ice age in Ireland (Albrecht, 1983) and therefore its presence may have resulted from human transplantations that could have resulted in a genetic differentiation from continental populations by founder effect. Albrecht (1983) supposed a recent origin of crayfish in Ireland by human transport in the 19th century but its origin is not clearly known (Reynolds, 1997). Lucey (1999) has unravelled the recent history of crayfish in Ireland and linked their documented presence around 1600 to introduction from England, while Reynolds (1997) has suggested they may have been introduced by monastic orders from western France as early as the 12th century. Although our results do not allow us to determine the precise origin of translocated animals, it is evident that Irish crayfish stocks originated from Atlantic ones. Further work is now in progress on several populations in order to clarify the origin of $A$. pallipes in Ireland.

\section{Acknowledgements}

Thanks are due to M. Raimond for technical assistance and to D.M. Holdich (U.K.), W.D. Rogers (U.K.), F. Marnell (Irish Wildlife service) and H.J. Troschel (Germany), as well to all the members of the Délégations Régionales of the Conseil Supérieur de la Pêche (C.S.P.), for assistance with collecting the crayfish samples. This work was supported by a grant from the Région PoitouCharentes and financial support from the C.S.P.

\section{References}

ALBRECHT, H. 1983. Besiedlungsgeschichte und ursprünglich holozane verbreitung der europäischen Flusskrebse. Spixiana, 6, 61-77.

(c) The Genetics Society of Great Britain, Heredity, 87, 80-87. 
ATTARD, J. AND VIANET, R. 1985. Variabilité génétique et morphologique de cinq populations de l'écrevisse européenne Austropotamobius pallipes (Lereboullet 1858) (Crustacea, Decapoda). Can J. Zool., 63, 2933-2939.

BAILlie, J. AND GROOMBridge, B. 1996. IUCN Red List of Threatened Animals. IUCN, Gland.

EXCOFfIER, L., SMOUSE, P. E. AND QUATTRO, J. M. 1992. Analysis of molecular variance inferred from metric distances among DNA haplotypes: application to human mitochondrial DNA restriction data. Genetics, 131, 479-491.

FELSENSTEIN, J. 1993. PHYLIP (Phylogeny Inference Package), v.3.5.c. Distributed by the author, Department of Genetics. University of Washington, Seattle, WA.

FRITSCH, P. AND RIESEBERG, L. H. 1996. The use of random amplified polymorphic DNA (RAPD) in conservation genetics. In: Smith, T. B. and Wayne, R. K. (eds) Molecular Genetics Approaches in Conservation, pp. 54-73. Oxford University Press, Oxford.

FUEREDER, L. AND MACHINO, Y. 1995. Record of the whiteclawed crayfish Austropotamobius pallipes (Lereboullet, 1858) from Plansee (Tyrol, Austria). Ber. Naturwiss.-Med. Ver. Innsbruck, 82, 241-246.

GRANDJEAN, F., SOUTY-GROSSET, C., RAIMOND, R. AND HOLDICH, D. M. 1997. Geographical variation of mitochondrial DNA between populations of the white-clawed crayfish Austropotamobius pallipes. Freshwater Biol., 37, 493-501.

GRANDJEAN, F., HARRIS, D. J., SOUTY-GROSSET, C. AND CRANDALL, K. A. 2000a. Systematics of the European endangered crayfish species Austropotamobius pallipes (Decapoda: astacidae). J. Crust. Biol., 20, 522-529.

GRANDJEAN, F., CORNUAult, B., ARCHAMbault, S., BRAMARD, M. AND OSTREBSKY, G. 2000b. Life history and population biology of the white-clawed crayfish, Austropotamobius pallipes, in a brook from the Poitou-Charentes region (France). Bull. Fr. Pêche Pisc., 356, 55-70.

GRANDJEAN, F., GOUIN, N., SOUTY-GROSSET, C. AND DIÉGUEZURIBEONDO, J. 2001. Drastic bottlenecks in the endangered crayfish species Austropotamobius pallipes in Spain and implications for its colonization history. Heredity, 86, 431-438.

GUYOMARD, R. 1989. Diversité génétique de la truite commune. Bull. Fr. Pêche Pisc., 314, 118-135.

HÄNFLING, B. AND BRANDL, R. 1997. Genetic differentiation of the bullhead Cottus gobio L. across watersheds in Central Europe: evidence for two taxa. Heredity, 80, 110-117.

HEWITT, G. M. 1996. Some genetic consequences of ice ages, and their role in divergence and speciation. Biol. J. Linn. Soc., 58, 247-276.

LANDE, R. 1995. Mutation and conservation. Conserv. Biol., 9, $782-791$.

LARGIADÈR, C. R., HERGER, F., LÖRTSCHER, M. AND SCHOLL, A. 2000. Assessment of natural and artificial propagation of the white-clawed crayfish (Austropotamobius pallipes species complex) in the Alpine region with nuclear and mitochondrial markers. Mol. Ecol., 9, 25-37.

LÖRTSCHER, M., STUCKI, T. P., CLALUNA, M. AND SCHOLl, A. 1997. Phylogeographic structure of Austropotamobius pall- ipes populations in Switzerland. Bull. Fr. Pêche Pisc., 347, 649-661.

LUCEY, J. 1999. A chronological account of the crayfish in Ireland. Bull. Irish Biogeog. Soc., 23, 143-161.

LYNCH, M. AND MILligAN, B. G. 1994. Analysis of population genetic structure with RAPD markers. Mol. Ecol., 3, 91-99.

McELROY, D., MORAN, P., BERMINGHAM, E. AND KORNFIELD, I. 1992. REAP: an integrated environment for the manipulation and phylogenetic analysis of restriction data. J. Hered., 83, 157-158.

NEVo, E. T., BELles, A. AND BEN SHLOMO, R. 1984. The evolutionary significance of genetic diversity: ecological, demographic and life history correlates. In: Mani, G. S. (ed.) Evolutionary Dynamics of Genetic Diversity, Lecture notes in biomathematics 53, pp. 14-213. Springer, Berlin.

PERSAT, H. AND BERREBI, P. 1990. Relative ages of present populations of Barbus barbus and Barbus meridionalis (Cyprinidae) in southern France: preliminary considerations. Aquat. Living Resour., 3, 253-263.

RAYMOND, M. AND ROUSSET, F. 1995. An exact test for population differentiation. Evolution, 49, 1280-1283.

REYNOLDS, J. D. 1997. The present status of freshwater crayfish in Ireland. Bull. Fr. Pêche Pisc., 347, 693-700.

ROFF, D. A. AND BENTZEN, P. 1989. The statistical analysis of mitochondrial DNA polymorphism: $\chi^{2}$ and the problem of small samples. Mol. Biol. Evol., 6, 539-545.

SANTUCCI, F., IACONNELLI, M., ANDREANI, P., CIANCHI, R., NASCETTI, G. AND BULLINI, L. 1997. Allozyme diversity of European freshwater crayfish of the genus Austropotamobius. Bull. Fr. Pêche Pisc., 347, 663-676.

SCHNEIDER, S., KUEFFER, J.-M., ROESSLI, D. AND EXCOFFIER, L. 1997. ARLEQUIN, v.1.1: software for population genetic data analysis. http://anthropologie.unige.ch/arlequin.

SKROCH, P. AND NIENHUIS, J. 1995. Impact of scoring error and reproducibility of RAPD data on RAPD based estimates of genetic distance. Theor. Appl. Genet., 91, 1086-1092.

SOUTY-GROSSET, C., GRANDJEAN, F., RAIMOND, R., FRELON, M., DEBENEST, C. AND BRAMARD, M. 1997. Conservation genetics of the white-clawed crayfish Austropotamobius pallipes: the usefulness of the mitochondrial DNA marker. Bull. Fr. Pêche Pisc., 347, 677-692.

VILLINGER, E. 1986. Untersuchungen zur Flussgeschchte von Aare-Donau/Alpenrhein und zur Entwicklung des MalmKarsts in Südwestdeutschland. Jb. Geol. Landes. BadenWürtemberg, 28, 297-362.

WARD, R. D., WOODWARK, M. AND SKIBINSKI, D. O. F. 1994. A comparison of genetic diversity levels in marine, freshwater and anadromous fish. J. Fish Biol., 44, 213-232.

WILLIAMS, J. G. K., KUBELIK, A. R., LIVAK, K. J., RAFALSKI, J. A. AND TINGEY, S. V. 1990. DNA polymorphisms amplified by arbitrary primers are useful as genetic markers. Nucl. Acids Res., 18, 6531-6535.

WRIGHT, S. 1978. Evolution and Genetics of Populations. Vol. IV: Variability Within and Among Populations. University of Chicago Press, Chicago, IL.

YEH, F. C. 1999. POPGENE, v.1.31. Distributed by the author. http://www.ualberta.ca/ fyeh/fyeh. 